\title{
The AK Party and the Kurds since 2014: A Discourse of Terror
}

\section{Abstract}

The Adelet ve Kalkınma Partisi (AKP) government in Turkey has made full use of terrorism legislation. Since 2007, it has been used to prosecute and imprison journalists, academics, military officers, the police, judiciary and political opponents. In short, terrorism legislation has closed off opposition voices within the Turkish political scene. It has also been used to justify the bombardment of civilians in the Kurdish east of the country but not used, to the same degree, against followers of the Islamic State. This paper uses Critical Terrorism Theory to examine the underlying power structures at play within this scenario. It takes a Critical Discourse Analysis methodology on public statements by senior government figures, including President Recep Tayyip Erdoğan, to argue that the Turkish government has redefined terrorist to mean "opponent" and thereby utilized it instrumentally to consolidate its political power. Furthermore, the AKP has used the legislation selectively in favour of those adhering to its religious identity. This inconsistent application of terrorism legislation exposes the varying allegiances in Turkish politics and can explain the current illiberal trend and volatility.

Dr Natalie Martin Lecturer in Politics and International Relations Nottingham Trent University, Chaucer Street, Nottingham. NG1 4BU.

Tel: 0044 (0) 1158482908

Email: natalie.martin@ntu.ac.uk

Orcid.org/0000-0002-1036-5463

Twitter: @drnataliemartin

Word count: 9533 inclusive. 


\section{Introduction}

The Kurdish issue has been a major schism in Turkish politics since the establishment of the Republic in 1923 and has dominated the political and security scene since the PKK (Partiya Karkerên Kurdistan - Kurdistan Workers' Party) emerged in the 1980s. The AKP, at various times since it came to power, in 2002, has ostensibly tried to procure a ceasefire, if not a peace process, in the Kurdish "issue" but in the last three years the situation has deteriorated back to violence of the 1980s and 1990s. The PKK as a "terrorist" organisation is a "fact" in Turkish political discourse and that of the international mainstream. This paper argues that the AKP has utilised this "fact" of PKK terrorism as a political tool against other Kurdish actors to its own advantage.

Working within a critical theoretical and methodological framework, it argues that the "terrorist" label has been used to good effect to delegitimise the Syrian Kurdish PYD (Partiya Yekitiya Demokrat - Democratic Union Party) and the Turkish Kurdish HDP (Halklarin Demokratik Partisi - People's Democratic Party) by association with the PKK. This countered the influence of the PYD as an obstacle to Turkish state territorial gains in northern Syria and the HDP as a domestic political rival and potential obstacle to Recep Tayyip Erdoğan's executive presidential ambitions. At the same time, the AKP government chose not to apply this label to Iraqi Kurdish Peshmerga forces or Islamic State fighters with who, at that time, it had more mutually beneficial relations. Hence, it is argued, that some groups have been securitised and others de-securitised instrumentally.

More recently, the "terrorist" label has been applied to critical and or scrutinising groups such as academics and human rights activists who have expressed concern about the fate of civilians in the affected areas in the east of Turkey. They have been persecuted and, in some cases, prosecuted under terror legislation, for questioning government policy with regard to the Kurdish issue. The paper argues that the AKP has used terror legislation as a means of quelling political opposition in various forms and deterring it in the future. It also argues that the securitisation has the Turkish state as its referent object in the case of the PYD and the Islamic State after late 2015 but, more significantly, in the case of the HDP, the Academics for Peace signatories and human rights activists, the state was acting in the interests of the AKP itself - and specifically President Erdoğan. 
Hence, the paper concludes that this discursive strategy used by the AKP elite can be seen as another example of the authoritarian drift, which has been evident in Turkey since 2007. It is both a symptom of it and a means of sustaining it in the short and medium term.

\section{Critical Terrorism Studies and Securitisation theory}

This paper draws on the critical terrorism theoretical framework of Jackson ${ }^{1}$. As such, it questions the presumptions of "problem solving" or positivist approaches to the theoretical study of terrorism and political violence. This critique has been based on two primary grounds: that the presumptive work was neither rigorous nor based on sound primary research; secondly it failed to address issues of power underlying the use of the "terrorism" label. If these questions were not asked, Jackson argued, then the underlying power relationships would not be revealed.

Jackson instead proposed an alternative approach to the study of political violence and "terrorism" which is based within a critical approach to political theory and questions the possibility of objective theory ${ }^{2}$. So-called Critical Terrorism Studies critiques the assumption of "facts" and asks instead in whose interest is it to have "factual" information on terrorism and in whose interest is it that a given state of affairs is an accepted status quo. Jackson urges the student of "terrorism" to look for the politics - power - behind seemingly neutral knowledge about political violence. Its epistemology is post positivist and instead of presuming that "knowledge" is possible it examines competing views of the world and investigates the power relationship between them. Ontologically it argues that whilst political violence is a reality, "terrorism" is a social construct "...decided by social agreement and inter subjective practices." 3

For as Bryan outlines, the notion of "terrorism" is not value free and is therefore a problematic term. It can also be tautologous and not related to the specific action carried out.

\footnotetext{
${ }^{1}$ Richard Jackson, Writing the War on Terrorism: Language, Politics and Counter Terrorism. (Manchester: MUP, 2005)

2 Robert Cox, 'Social Forces, States and World Orders: Beyond International Relations Theory', Millennium: Journal of International Studies, 10, no. 2, (1981): 128.

3 Jackson, Writing the War on Terrorism, 248.
} 
"An act of violence is defined as terrorist not because of an analysis of the act but because a particular group are labelled as terrorist" 4

Moreover the ability of one group to label another terrorist is political because the "terrorist" label delegitimizes the motivation of the "terrorist" group. Bryan gives the example of the two sides in the northern Irish dispute in the UK. The nationalist Catholic side, the IRA (Irish Republican Army), were given the terrorist label but the unionist Protestant side, the UDA (Ulster Defence Association), much less so even though their tactics and the scale of their violence was similar. Hence Bryan and Jackson agree that it is vital to understand the power relationship inherent within the use of "terrorism" as a label in order to fully understand political violence.

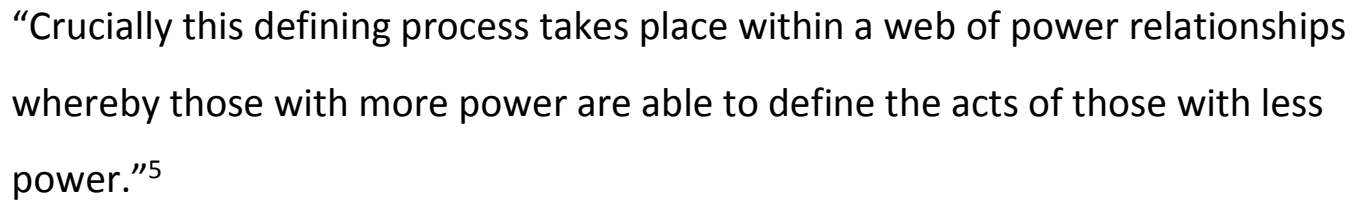

This paper also adopts the post-positivist approach to "terrorism". Furthermore, it does not preclude the state from being a "terrorist" actor and asks instead "....why, how and for what purpose do groups and individuals come to be named as terrorists and what consequences does this have?" In the study of terrorism there is no escaping the ethico-political content of the subject matter ${ }^{6}$. It is also crucial to understand that critical terrorism studies is not a "precise theory" but an "approach" to the study of political violence". It covers a wide range of theories from thick Social Constructivism through Critical Theory and Post-Structuralism.

This paper will specifically apply the securitisation theory of the Copenhagen School ${ }^{8}$ which sits broadly at the thick social constructivist end of the spectrum of critical approaches. Issues are not inherent security threats but become so “...by virtue of their presentation and acceptance as such..." ${ }^{9}$ Securitisation theory posits that when something is deemed to

\footnotetext{
${ }^{4}$ Dominic Bryan, 'A Landscape of Meaning: Constructing Understandings of Political Violence from the Broken Paradigm of 'Terrorism" in Contemporary Debates on Terrorism, eds. Richard Jackson and Samuel Sinclair, (London: Routledge, 2012), 17-24.

${ }^{5}$ Bryan, A Landscape of Meaning, 18.

${ }^{6}$ Jackson, Writing the War on Terrorism, 249.

${ }^{7}$ Jackson, Writing the War on Terrorism.

${ }^{8}$ Barry Buzan, Ole Waever and Jaap de Wilde, Security: A New Framework for Analysis (Boulder, Colorado: Lynne Reiner Press, 1998).

${ }^{9}$ Columba Peoples and Nick Vaughan-Williams, Critical Security Studies: An Introduction. (London: Routledge, 2010, 95).
} 
present an "existential threat" to what Buzan et al call the "referent object" it justifies an exceptional response to it. This is perhaps an obvious process when applied to a conventional military threat to a state (the referent object) which would justify the marshalling of troops and military hardware. Buzan et al argue that a similar logic can also be seen when "security" is defined more broadly to include political, environmental and social issues. Hence, with the Turkish state - and the AKP - as a referent object, "terrorism" and political violence can be seen as an existential threat and thereby securitized, or desecuritized, through "speech acts" according to the self-interests of the referent object. This retains a critical edge with the implication that the ability to "securitize" is a power relationship within a given context and this relationship needs to be highlighted. Fundamentally, securitisation is a political process. This paper therefore looks at the use of the terrorism label, by the AK Party government, in Turkey since the latter half of 2014.

\section{Critical Discourse Analysis}

The methodology required to answer the research question relates to the theoretical and metatheoretical framework. Critical approaches to the study of terrorism presume a constructivist and interpretivist metatheoretical view. The questions asked by these theories seek, in varying ways, to establish the nature of the social construction of reality and the power relations therein, by deconstructing the language or "discourse". Hence, the methodology is needed to deconstruct the language to reveal these power relationships ${ }^{10}$. However, just as critical approaches are not one thing but an "approach", so the discourse analysis applied by critical theorists is multifaceted and is a body of methodology - rather than a single entity - each driven by its theoretical presumptions. For this reason, van Dijk ${ }^{11}$ urges proponents to view CDA as a body of work with the umbrella title of Critical Discourse Studies (CDS) - rather than as a single methodology. These range from the "analysis of discourse" to definitively "Critical" Discourse Analysis (CDA). Within the variants, there are subcategories and the precise form of Critical Discourse Analysis, will depend on which

\footnotetext{
${ }^{10}$ Ruth Wodak and Michael Meyer, Methods of Critical Discourse Studies (London, Sage, $20153^{\text {rd }}$ ed.)

${ }^{11}$ Teun van Dijk, Discourse and Knowledge: A Sociocognitive Approach (Cambridge, Cambridge University Press, 2014)
} 
aspect of a critical theoretical approach is taken. The actual method will vary according to the question being asked and that will depend on the theoretical framework chosen.

The notion of "discourse" is also contested or should be seen, at the very least, as a manifold concept. For the purposes of this paper "discourse" is viewed as the publically reported statements of the elite level of the AKP since 2014. It assumes that the speeches and public comments of President Recep Tayyip Erdoğan, the one-time Prime Minister Ahmet Davutoğlu and Foreign Minister Mevlut Çavuşoğlu constitute an influential body of opinion in Turkish politics with the underlying presumption of language as social practice. Erdoğan's discourse is particularly dominant and "helps to sustain and reproduce the social status quo". In so doing it is "socially consequential and gives rise to important issues of power..." which "produce and reproduce unequal power relations". ${ }^{12}$ However "discourse" is more than just stark text or talk, it is the discursive practice by which zeitgeists are created or boundaries, of what is normal or acceptable in a given time and space, are set. Hence, "discourse" is a "multidimensional, multimodal and multifunctional phenomenon" which is created by the world around it which also influences the world around it ${ }^{13}$. In deconstructing the discourse of Erdoğan from a critical viewpoint, we are asking why this discourse is setting these particular boundaries of what is "true" or "normal". In whose interest is this particular zeitgeist?

Hence, the sources are publically-reported comments by President Recep Tayyip Erdoğan and other senior members of his AKP government 2014-17 on the following: the PKK, the PYD and YPG (Yekîneyên Parastina Gel- People's Protection Units), the HDP and the Islamic State/Daesh. This will encompass the siege of Kobane, the two Turkish general elections of 2015, the attempted coup d'état in July 2016 and the presidential referendum of April 2017. The Erdoğan discourse will be harvested from the Nexis media database from English language sources (primarily Agence France Presse) corroborated with Anatolia News Agency reports (in English). Specifically it will operationalize the Discourse-Historical Approach

\footnotetext{
12 Norman Fairclough and Ruth Wodak, 'Critical Discourse Analysis', in Discourse as Social Interaction, ed. Teun van Dijk, (London: Sage, 1997), 258.

${ }^{13}$ Christopher Hart and Piotr Cap, Contemporary Critical Discourse Studies (London, Bloomsbury, 2014 ), 4.
} 
$(\mathrm{DHA})^{14}$, which has an emphasis on discourse as indicated above within the wider context of the subject under scrutiny.

\section{Types of terror in Turkey}

The use of "terrorism" in public discourse has been an established feature of the Kurdish issue in Turkey since the late $1980 \mathrm{~s}^{15}$. Moreover, the PKK has been on the USA State Department's list of terror organisations since $1997^{16}$ and the EU's since $2001^{17}$, which has reinforced the international mainstream view of the PKK as "terrorists", rather than purveyors of political violence in the separatist cause ${ }^{18}$. Since 2007 , however, the label of terrorism has been applied to groups outside of the PKK and this can be seen as a symptom of "authoritarian drift" in Turkish society ${ }^{19}$. Terrorism has been used as a means of prosecuting - and therefore silencing - critical, but also merely scrutinising voices. The initial phase of authoritarian drift - and instrumental use of the "terrorist" label - is evident since 2007 in the Ergenekon and subsequent Balyoz investigations, which first targeted the Kemalist military establishment elite before widening its net to include journalists and academics $^{20}$. It is also evident after 2009 in the KCK investigations (Koma Civakên Kurdistan - Kurdish Communities' Union) in which practicing journalism about Kurdish issues was enough to be labelled a sympathiser and charged with terror offences ${ }^{21}$.

\footnotetext{
${ }^{14}$ Martin Reisigl, and Ruth Wodak, 'The Discourse-Historical Approach (DHA)' in Methods of Critical Discourse Studies, ed. Ruth Wodak, \& Michael Meyer, (London: Sage, 2015, 3rd ed.) 87-121.

${ }^{15}$ André Barrinha, 'The Political Importance of Labelling: Terrorism and Turkey's Discourse on the PKK', Critical Studies on Terrorism, 4, no. 2, (2011): 163-180.

${ }^{16}$ US Department of State, List of Foreign Terrorist Organisations, available at: https://www.state.gov/i/ct/rls/other/des/123085.htm

${ }^{17}$ Council of the European Union -EU Terrorist List, available at: http://www.consilium.europa.eu/en/policies/fight-against-terrorism/terrorist-list/

18 Ofra Bengio, 'The "Kurdish Spring" in Turkey and its Impact on Turkish Foreign Relations in the Middle East', Turkish Studies, 12, no. 4, (2011): 619-632; Cengiz Gunes, 'Mobilisation of Kurds in Turkey during the 1980s and 1990s', in The Kurdish Question Revisited, eds. Gareth Stansfield and Mohammed Shareef, (London: Hurst and Company, 2017), 187-198.

${ }^{19}$ Ergun Özbudun, 'AKP at the Crossroads: Erdoğan's Majoritarian Drift', South European Society and Politics, 19, no. 2, (2014): 155-167; Berk Esen and Sebnem Gumuscu, 'Rising competitive authoritarianism in Turkey', Third World Quarterly, 37, no. 9, (2016): 1581-1606.

${ }^{20}$ Senem Aydin-Duzgit and Fuat Keyman, 'EU Turkey Relations and the Stagnation of Turkish Democracy', Global Turkey in Europe Working Paper No 2. (2012). http://www.iai.it/sites/default/files/GTE WP 02.pdf ${ }^{21}$ Seevan Saeed, Kurdish Politics in Turkey: From the PKK to the KCK, (London, Routledge. 2014); Bill Park, Turkey's Kurdish Problem, The Kurds' Turkish Problems, in The Kurdish Question Revisited, eds. Gareth Stansfield and Mohammed Shareef, (London: Hurst and Company, 2017), 199-210.
} 
Such authoritarianism can be seen as part of the "backlash against democracy" across the world $^{22}$. However, when considering authoritarianism in Turkey it should be noted that it is not a new phenomenon. The AKP is the latest in a long line of illiberal governments.

Turkey's current 2016 Freedom House Freedom of the World rating of "partly free" (3.5 on a scale of 1-7) actually compares favourably to the $1999-2002$ rating of $4.5 .{ }^{23}$ At that time the military had a track record of at least three military coup d'états since 1960 . There were also persistent rumours of 'deep state' plots such as the Susurluk conspiracy in $1996^{24}$, "systematic and widespread" state torture (Amnesty 2001) and an authoritarian response to Kurdish insurgency in the east of the country ${ }^{25}$.

The securitisation of "terrorism" by the state can be seen in the case of the PKK since the $1980 s^{26}$. However, this paper deals specifically with the period of time since 2007 and focusses on the use of "terror" legislation against Kurdish subjects. This was the point when the AKP lost faith in the willingness of the EU to ever offer accession and instead began to consolidate its domestic power. The AKP was determined to vanquish the Kemalist secular establishment in Turkey in order to obtain religious freedoms and set about "...establishing the full scale control of all the autonomous agencies of the state." 27 . This authoritarian drift was a return to the illiberality seen under previous Kemalist regimes - with the locus of power reversed ${ }^{28}$. Whilst the origins of declining AKP commitment to liberality can be traced back to at least 2007, the pace and extent of authoritarian drift certainly quickened after 2010/11 as the AKP consolidated power buoyed by its electoral success in the 2010 constitutional referendum and the 2011 general election. The cumulative result was the removal of checks and balances within the Turkish political system and increasing authoritarianism.

\footnotetext{
${ }^{22}$ Larry Diamond, Marc F. Plattner, and Christopher Walker (eds.) Authoritarianism Goes Global, (New York, John Hopkins University Press, 2016).

${ }^{23}$ Freedom House research centre. See: https://freedomhouse.org/report/freedom-world/2016/turkey

24 James Meyer, 'Politics as usual: Ciller, Refah and Susurluk: Turkey's Troubled Democracy', East European Quarterly, 32, no. 4, (1998): 489-502.

${ }^{25}$ For background on this issue see: Henry Barkey and Graham. E. Fuller, Turkey's Kurdish Question (Lanham, MD: Rowman \& Littlefield, 1998); Kemal Kirisci and Gareth M. Winrow, The Kurdish Question and Turkey: An Example of a Trans-State Ethnic Conflict (London: Frank Cass, 1997); and Alizia Marcus, Blood and Belief: The PKK and the Kurdish Fight for Independence (New York: New York University Press, 2007).

${ }^{26}$ Barrinha, 'The Political Importance of Labelling'.

${ }^{27}$ Ersin Kalaycıoğlu, 'The Turkish-EU Odyssey and Political Regime Change in Turkey', South European Society and Politics, 16, no. 2, (2011): 274.

${ }^{28}$ Omer Taşpinar, 'The End of the Turkish Model', Survival, 56, no. 2, (2011): 49-64.
} 
This paper argues that the speed of authoritarian drift has quickened again since the split with the Gülen movement in December 2013. Moreover, since 2014 there has been a gradual resumption of hostilities in the Kurdish "issue" which led to the breakdown of the ceasefire with the PKK in July 2015. Both Gülenists and Kurdish associated groups have since been the subject of this terrorism securitisation strategy and in both cases this should be seen as a result of the consolidation of power in the AKP loyal to Recep Tayyip Erdoğan. It focusses in particular on the Kurdish issue and examines AKP elite discourse regarding the Syrian Kurds and the PKK, and the Turkish Kurdish political party, the HDP, and the PKK. It argues that the instrumental use of "terror" as a political tool should be seen as a symptom of authoritarian drift in Turkey which is in evidence since 2007. More specifically the use of terrorism discourse since $2014 / 15$ can specifically be seen as a means of delegitimising political opponents and critical or scrutinising voices whose success was a threat to the smooth passage of an executive presidency. It will begin by examining the discourse surrounding the PYD and the YPG in northern Syria, then the HDP since 2015 and Islamic State.

\section{Good Kurds and bad Kurds: Peshmerga and the PYD}

In late 2014 the tentative on-off peace between the PKK and the Turkish state - which had most recently begun with the 2009 "democratic opening" initiative ${ }^{29}$ - began to unravel. There had been ongoing mistrust between the AKP and the Kurdish population in Turkey over both sides' sincerity in the peace process which had had several false starts and setbacks ${ }^{30}$. This was exacerbated by the Turkish government's reaction to the assault by Islamic State (Daesh) forces on the Syrian-Kurdish town of Kobane in 2014 and the discursive conflation of Syrian-Kurdish forces fighting Islamic State with the PKK.

Part of the disquiet stemmed from the Turkish government's policy of containing Syrian Kurdish refugees, from Kobane and the surrounding area, within a "humanitarian buffer zone" near the border ${ }^{31}$. This was then aggravated by Ankara's decision not to allow Turkish Kurds to cross the border to fight Islamic State in Kobane. Moreover, demonstrations

\footnotetext{
${ }^{29}$ Ofra Bengio, "The "Kurdish Spring"; International Crisis Group, 'Turkey and the PKK: Saving the Peace Process. Europe Report N²34, November 6, 2014. https://www.crisisgroup.org/europe-central-asia/westerneuropemediterranean/turkey/turkey-and-pkk-saving-peace-process

30 Park, Turkey's Kurdish Problem.

31 'More than 130,000 Syrian Kurds flee to Turkey', Agence France Presse, September 22, 2014.
} 
against this policy were condemned by Erdoğan as attempts by "dark forces" to "sabotage" the fragile ceasefire with the PKK. ${ }^{32}$ Soon after, Iraqi Kurdish Peshmerga guerrillas were permitted to cross the border from Turkey to fight in Kobane and the Turkish government agreed a plan with the USA to train "moderates" within the anti-Assad opposition Free Syrian Army (FSA) to combat IS - whilst the Turkish Kurds remained forbidden from doing $\mathrm{so}^{33}$.

Erdoğan justified this action by "demonising" ${ }^{34}$ the Syrian Kurdish political party, the PYD which Ankara described as a "terror group just the same as the PKK..." ${ }^{35}$ These comments implied that any assistance for the PYD against IS would be to assist the PKK in its insurgency against Turkish state forces. This conflated the PYD, and its militia, the YPG, with the PKK: whilst they have connections, political, operational and familial, they are not the same thing and were not acting for the same reasons. The PYD/YPG was involved in a civil war against the Syrian state, and also in an insurgency against a non-state actor (IS). The PKK's primary activity is as a separatist movement against the Turkish state.

Furthermore Erdoğan described the Free Syrian Army involvement as a "beneficial step" which would spoil the PYD's "scheme and trap" in Kobane ${ }^{36}$ and this discourse was backed by the Prime Minister Ahmet Davutoğlu ${ }^{37}$. This rhetoric led to an angry reaction in Kurdish areas of south east Turkey where it was felt the Syrian Kurds were being undermined by association with a proscribed terrorist group and left to their fate at the hands of Islamic State. This resulted in a "rise in the status" of both the PYD and the PKK amongst Syrian and Turkish Kurds and a corresponding loss of electoral support for the AKP 38 . In so doing Erdoğan created a binary choice of "good Kurds" (Iraqi Peshmerga) and bad Kurds (PKK/PYD/YPG). Moreover it seemed Erdoğan was engaged in seeking to exacerbate

\footnotetext{
32 'Erdoğan denounces Turkey protests as peace process 'sabotage", Agence France Presse, October 9, 2014.

33 'Turkey, US agree plan to train 2,000 moderate Syrian rebels: report', Agence France Presse, November 15, 2014.

${ }^{34}$ Park, Turkey's Kurdish Problem, 203.

35 'Erdoğan says Syrian Kurds 'don't want' Peshmerga in Kobane', Agence France Presse, October 26, 2014.

36 'Erdoğan says Syrian Kurds 'don't want' Peshmerga in Kobane', Agence France Presse, October 26, 2014.

37 'Turkey walks tightrope over Kobane after Peshmerga deployment', Agence France Presse, November 6, 2014.

38 Park, Turkey's Kurdish Problem, 205.
} 
rivalries across ethnic and nationalist lines: between Syrian and Iraqi Kurds and Syrian Kurds and the Free Syrian Army. He said:

"The PYD does not want the Peshmerga to come. They don't want the Peshmerga to come to Kobane and dominate it. The PYD thinks its game will be spoilt if the Peshmerga come. Their setup will be ruined." 39

Hence in its reaction to Kobane the Turkish government labelled the PYD, a political party, as "terrorist" and sought to differentiate it from the Iraqi Peshmerga Kurdish forces for doing the same thing - defending the town of Kobane against Islamic State. In so doing the AKP government accepted the need for Kobane to be defended by Iraqi Peshmerga but appeared to seek to delegitimize the Syrian (and Turkish) Kurds' attempts to do so by rhetorically associating Syrian Kurdish actors with "terrorism" by associating them with the PKK which is internationally recognized as being a "terrorist" organisation. The AKP had the power and motivation to describe the political violence in self defence against Islamic State of the PYD and the YPG as "terrorism". The implication is that Erdoğan and the AKP saw the PYD as a political threat in the sense that territory gained might by an asset to the PKK in its conflict with the Turkish state and the discursive securitisation of the Syrian Kurdish groups has continued. Given the difficulties this "demonisation" of the Syrian Kurdish forces caused between Ankara and the USA, plus NATO, the only conclusion is that the PYD, and the wider Kurdish cause, were seen as both an existential threat to the AKP's electoral power base and a threat to the Turkish state's power and influence in northern Syria for the discursive strategy has continued. In January 2015 Erdoğan said he would not allow a “..terrorist group to establish camps in northern Syria"40; in the summer of 2015 the Turkish state was targeting Kurdish facilities in norther Iraq as well as IS in Syria - and continuing to conflate the PYD, PKK and IS collectively as "terrorists" ${ }^{41}$. Following the bomb at a pro-Kurdish rally in Ankara in October 2015, which killed around 100 people and injured many more, Erdoğan attributed blame to a "terror collective" which, he said, included the PYD. ${ }^{42}$

\footnotetext{
39 'Kurds thwart new IS bid to cut off Syria's Kobane', Agence France Presse, October 26, 2014.

40 'Turkey's Erdoğan_says no to Syrian Kurdistan', Agence France Presse, January 27, 2015.

41 'Forced to strike IS, Turkey gambles on attacking PKK', Agence France Presse, July 27, 2015.

42 'Ankara bombing 'collective terrorist act': Erdoğan', Agence France Presse, October 22, 2015.
} 


\section{The rise and fall of the HDP}

This rhetorical device of delegitimising one group by conflating it with the PKK - a listed "terror" organisation - was repeated in 2015 regarding the HDP (Halklarin Demokratik Partisi - People's Democratic Party). The HDP had roots in the Kurdish issue but also had wider, progressive, appeal and had benefitted from the heightened sense of Kurdish identity and affiliation which resulted from the disquiet over events at Kobane ${ }^{43}$. In the June 2015 Turkish general election it exceeded the $10 \%$ threshold necessary to sit in the Turkish parliament and won an unprecedented 80 seats or $13 \%$ of the vote ${ }^{44}$. This encroached on the AKP's vote and prevented it from achieving a full majority in parliament ${ }^{45}$. Attempts to form a coalition thereafter did not work and a second general election was called for November $1^{\text {st }} 2015^{46}$. In this second election, the HDP's number of seats dropped to 59 seats enabling the AKP to form a single party government ${ }^{47}$.

In the interim, it is argued here, that the HDP was discredited through a discursive strategy of associating it with the PKK. This followed the resumption of hostilities between the Turkish state and the PKK after the Suruç bombing of July $2015^{48}$. More than 30 people died and around 100 more were injured by a device, attributed to Islamic State by the Turkish government ${ }^{49}$, planted in a cultural centre which was hosting young activists preparing to go to Kobane to help with repairs. It exacerbated the existing tensions between the government and the PKK, which had been rising since the year before, and led to immediate retaliation and marked deterioration of the security situation in south east Turkey ${ }^{50}$. Just a few days after, the Turkish government gave permission to the USA to use Incirlik airbase ${ }^{51}$.

The discursive environment surrounding the AKP and the HDP then became firmly embedded in a terrorist narrative. In the week after the Suruç bombing the Turkish

\footnotetext{
${ }^{43}$ Henry Barkey, 'The Transformation of Turkey's Kurdish Question' in The Kurdish Question Revisited, eds. Gareth Stansfield and Mohammed Shareef, (London: Hurst and Company, 2017), 211-224.

44 'Turkey ruling party weighs options after election blow', Agence France Presse, June 8, 2015.

45 This was significant as it stopped Erdoğan from being able to pass his constitutional changes towards an executive presidency unopposed.

46 'Turkey to vote on Nov 1, PM to form caretaker government' Agence France Presse, August 25, 2015.

47 'Joy and anguish greet AKP win in Turkey vote', Agence France Presse November 1, 2015.

48 'Suicide bomber kills 31 in Turkey attack blamed on IS', Agence France Presse, July 20, 2015.

49 'Shocked Turkey steps up security after deadly border attack', Agence France Presse, July 21, 2015.

50 'PKK claims killing Turkish police to avenge 'IS bombing' Agence France Presse, July 22, 2015.

51 'Turkey strikes on Kurdish bases in Iraq puts truce in danger', Agence France Presse, July 25, 2015.
} 
government carried out the airstrikes on Islamic State in Syria and the PKK in northern Iraq. The Prime Minister Ahmed Davutoğlu said they were to prevent Turkey being turned into a "lawless country" ${ }^{2}$. The two separate and opposing groups - the PKK and IS - were thus conflated into one "terror threat" to Turkey's rule of law with no acknowledgement of the differences between them. The foreign minister, Mevlüt Çavuşoğlu, justified the strategy by alleging the PKK was: "...taking advantage of the situation in the region, of the fact that Turkey has begun fighting (IS) and they have stepped up their attacks and terrorist activities in Turkey. That's why we must also reach PKK targets in northern Iraq."

He added:

"You cannot say that the PKK are better than (IS) because they are fighting against them. They are fighting among each other for power, not for peace, or for security."

Çavuşoğlu then said the HDP was "affiliated with the PKK" and "could be an important mediator......but instead they are calling on Kurdish citizens to take up arms, to demonstrate, to disturb public order" 53 .

On July $30^{\text {th }} 2015$ the government began an investigation into the co-leader of the HDP, Selahattin Demirtaş ${ }^{54}$, for inciting violence. This referred to a statement by the HDP in October 2014 during the Kobane crisis which had encouraged supporters to protest against Turkish government policy on the passage of Turkish Kurds to Kobane ${ }^{55}$. Erdoğan also referred to the HDP as "The party that is controlled by a terrorist organisation" 56 and in September 2015 the state prosecutor opened an investigation into Demirtaş and his coleader Figen Yüksekdağ on allegations of "insulting the nation" and "making propaganda for a terror group" 57 . During the campaign for the second election the conflict with the PKK was headline news and Erdoğan continued to accuse the HDP of being a front for the PKK: "You succeeded in (deceiving the people) on June 7 but I believe that you will be unable to so on

\footnotetext{
52 'Turkey strikes on Kurdish bases in Iraq puts truce in danger', Agence France Presse, July 25, 2015.

53 'PKK 'never respected' peace process: Turkey', Agence France Presse, July 27, 2015.

54 The other co-leader is Figen Yuksekdag

55 'At least 14 dead as protests rage in Turkey over Kobane', Agence France Presse, October 8, 2014.

56 'Erdoğan vows no let-up in fight against Kurdish rebels', Agence France Presse, August 12, 2015.

57 'Turkey blocks pro-Kurdish MPs from curfew city after deadly fighting', Agence France Presse, September 10, 2015.
} 
November $1^{1158}$. He then offered a strong AKP government as an antidote to continuing unrest saying that "the people who threaten our country with arms and with bombs" would lead it "into the dark tunnels of terrorism"59.

The effect of this was to associate the mainstream HDP political party with the political violence of the PKK and its military wing, the HPG (Hezen Parastina Gel - People's Defence Units) and this was made easier by the fact that Demirtaş' brother, Nurettin, was an active member of the PKK. In spite of the HDP's calls for a ceasefire and reopening of talks in the summer of 2015 it forced Selahattin Demirtaş to deny the HDP was "....a party of the PKK, nor its political wing." ${ }^{60}$ The cumulative effect of this discourse undermined Demirtaş' credibility in Turkey and this was reflected in the November 2015 general election result.

\section{Islamic State: de-securitisation to re-securitisation}

This paper has sought to demonstrate the discursive strategy of the AKP government in Turkey towards the Kurdish affiliated groups the PYD/YPG in Syria and the HDP in Turkey. It has been argued that in both cases the label of "terrorism" was used to discredit them and utilizes the critical terrorism approach of Jackson (2005) by arguing that in both cases these groups were securitized instrumentally to benefit the referent object - AKP government. In this section the case of AKP discourse on Islamic State is examined to demonstrate how this process can also work in reverse. Discourse can also de-securitize an actor for instrumental benefit.

On October $10^{\text {th }} 2015$ a suicide bomb attack on a rally in Ankara calling for peace in eastern Turkey killed more than 100 people and injured many more. The rally was progressive, proKurdish (and pro-HDP) and primarily called for an end to hostilities between the PKK and the Turkish state. On October $22^{\text {nd }} 2015$ President Erdoğan implied the PKK, and by association the HDP, had bombed its own sympathizers in association with Islamic State, the Syrian secret police (the Mukhabarat) and the Syrian Kurdish party, the PYD. He said the Ankara

\footnotetext{
58 'Turkey's Erdoğan vows no let-up in fight against PKK', Agence France Presse, September 29, 2015.

59 'Joy and anguish greet AKP win in Turkey vote', Agence France Presse, November 1, 2015.

60 'Demirtaş the 'Kurdish Obama' faces his biggest test', Agence France Presse, July 31, 2015.
} 
attack had been carried out by a "terrorist collective" 61 and branded the HDP as an "accomplice" of the PKK ${ }^{62}$ : "They have the audacity to speak of peace... but that means blood". ${ }^{63}$ Having already associated the HDP with PKK terrorism, in so doing Erdoğan also discursively constructed the HDP as, by implication, a collaborator of Islamic State as well, notwithstanding the two groups' deep mutual animosity on many levels.

This is in marked contrast to the AKP's discourse on Islamic State. After the Ankara bomb in October 2015, government sources identified the bomber as an IS operative with possible links to the Suruç (July 2015) bomber. However, whilst this was a public admission of the role of Islamic State in the Ankara bombing, senior government officials had also linked it to the PKK - even though it was a pro-Kurdish rally. Erdoğan spoke of the Ankara bombing as a "heinous attack" aimed at ".... our unity and our country's peace..." 64 with no acknowledgement of the primary political and ethnic - Kurdish - orientation, or sympathies for, of the majority of the victims. Instead it seemed to be an opportunity to damage the HDP's electoral chances by associating it with a terrorist act.

Moreover, until the Suruç bombing of July 2015 , the AKP had seemed reluctant to apply "terror" discourse to Islamic State. Indeed the former EU Ambassador to Turkey Marc Pierini asked at this time whether Turkey was treating Islamic State “...as a terrorist organisation or as a diplomatic interlocutor" 65 . Instead, Turkey was as concerned to label Bashar Al Assad a purveyor of "state terror", as well as the PKK, as it was to condemn Islamic State over Kobane and other atrocities. This caused problems in the transatlantic relationship as Washington was concentrating on the defeat of IS and the reluctance to allow Incirlik airbase to be used as a base for sorties against IS prior to July 2015 was a cause of frustration. The US Vice President Joe Biden was forced to "clarify" remarks he made in October 2014 implying implicit Turkish support for anti-Assad Islamist forces in Syria had

\footnotetext{
61 'Ankara bombing 'collective terrorist act': Erdoğan', Agence France Presse, October 22, 2015.

62 'Erdoğan party hits the hustings ahead of Turkey vote', Agence France Presse, October 25, 2015.

63 'Pro-Kurdish party under pressure ahead of Turkey vote', Agence France Presse, October 27, 2015.

64 'At least 86 killed in Turkey's deadliest attack', Agence France Presse, October 10, 2015.

65 Marc Pierini, Carnegie Europe, September 22, 2014, 'Tensions on the Turkish border',

http://carnegieeurope.eu/strategiceurope/?fa $=56694$
} 
encouraged the rise of $I S^{66}$ and Biden visited Turkey in November 2014 in order to persuade Erdoğan to do more for the anti IS coalition ${ }^{67}$.

The AKP's attitude to Islamic State began to change in June-July 2015: Two bombs detonated in the predominantly Kurdish city of Diyarbakır in eastern Turkey on June $5^{\text {th }}$ 2015 at a HDP rally just before the general election. Four people died and another 100 were injured. Whilst the HDP blamed Islamic State ${ }^{68}$, the government did not attribute blame to an organisation at the time. However, following the Suruç explosion just a few weeks later, the Turkish Prime Minister, Ahmet Davutoğlu, accepted that IS was to blame and had acted as a terror organisation but, nevertheless, said nothing about the ethnic identity of those killed and injured and instead focussed on the Turkish state as a victim of terror ${ }^{69}$. It was in the aftermath of the Suruç attack that Turkey launched airstrikes on Islamic State targets in Syria - (and PKK bases in northern Iraq). ${ }^{70}$

After early spring 2016, Islamic State was being clearly identified within elite AKP discourse as a terrorist organisation for two primary reasons: Firstly, the bombing in January 2016 outside the Ottoman Topkapi Palace in the tourist Sultanahmet district of Istanbul in which 11 German tourists died which was attributed to IS. This intensified again in March 2016 when a suicide bomber killed four people on the shopping street, Istiklal Caddesi in central downtown Istanbul. ${ }^{71}$ Erdoğan urged Turks to stand tall against terrorism and pledged to defeat Islamic State and the PKK - even though the PKK was not implicated in the Istiklal incident (Although a PKK offshoot the TAK had been implicated in other recent incidents). "We will hit these terrorist organisations as hard as possible...we will... quickly overcome them." 72

The second factor is the Islamic State attacks in Paris in November 2015 and in Brussels in March 2016. On both occasions, Erdoğan was quick to place Turkey as a victim of terrorism as well and express solidarity. After Paris he called for "a consensus of the international community against terrorism". He said: "As a country that knows very well the manner and

\footnotetext{
66 'Biden apologizes to Turkey's Erdoğan over jihadist funding claim', Agence France Presse, October 4, 2014.

67 'Biden, Erdoğan seek to ease narrow differences on Syria', Agence France Presse, November 22, 2014.

68 'Fourth victim dies from attack on Turkey party rally', Agence France Presse, June 13, 2015.

69 'Initial findings show IS carried out bomb attack: Turkey PM', Agence France Presse, July 20, 2015.

70 'Nearly 400 Kurdish rebels killed in 2 weeks of airstrikes: report', Agence France Presse, August 9, 2015.

71 'Erdoğan rallies Turks against unprecedented terror wave', Agence France Presse, March 21, 2016.

72 'Erdoğan rallies Turks against unprecedented terror wave', Agence France Presse, March 21, 2016.
} 
consequences of terrorism, we understand perfectly the suffering that France is experiencing now..."73 After the Brussels attacks he said:

"The terrorists who targeted Brussels, after attacks recently by the PKK (Kurdistan Workers' Party) in Ankara and Daesh in Istanbul that cost dozens of lives, are showing once again that they respect no value nor any human and moral limit,"

Thus Erdoğan used these incidents instrumentally to garner sympathy for Turkey as a fellow victim of Islamic State "terrorism" and also equated the Islamic State with the PKK - and hence by implication with both the PYD and the HDP.

\section{Critical and scrutinising voices: Academics for Peace and Amnesty}

\section{International}

It is further argued here that the discursive strategy seen so far with regard to the PYD and HDP has also been applied to less obvious critical voices in academia and civil society. Around 2015/16, the terror rhetoric regarding the Kurds begins to blur with that against the Gülen movement (or FETÖ) and often those accused were not sure with which one they were being associated. This is especially true with regard to critical and scrutinising voices as opposed to political organisations. This paper will concentrate on these matters as they intersect with the Kurdish issue.

In January 2016 more than a thousand academics in Turkey, and beyond, signed a petition calling for an end to hostilities in eastern Turkey. The "academics for peace" (Barış İçin Akademisyenler) petition came amidst allegations of human rights abuses against civilians in the eastern towns such as Cizre and Nusaybin. In August 2015 they were amongst several towns in eastern Turkey to declare self-governance in protest at the resumption of hostilities with the state and the PKK. The towns were subsequently placed under curfew, ostensibly to "protect" civilians and the military targeted PKK militants. Numerous reports were emerging at that time, which have since been substantiated by the $U N^{74}$, of civilians,

\footnotetext{
73 'Turkey's Erdoğan seeks 'anti-terror consensus' after Paris attacks', Agence France Presse, November 14, 2015.

${ }^{74}$ The United Nations Human Rights, Office of the High Commissioner, Report on the Human Rights situation in South-East Turkey July 2015-December 2016. February 2017, http://www.ohchr.org/Documents/Countries/TR/OHCHR South-East TurkeyReport 10March2017.pdf
} 
including children, being caught in the crossfire between Turkish forces and PKK operatives without access to food or medical treatment. The AKP government insisted the PKK were using civilians as cover. ${ }^{75}$

The Academics for Peace petition called on the Turkish government to "...abandon its deliberate massacre and deportation of Kurdish and other peoples in the region...". In response the government launched an investigation into the 1,128 signatories on various charges, of terrorism, inciting violence and insulting the state. Moreover, Erdoğan described those concerned as "...people in the dark. You are not intellectuals! All you want is to stir up this country..." and accused them of being agents of foreign powers. ${ }^{76}$ Since then a significant number of those involved have been arrested and charged. At the time of writing (December 2017) 148 individual trials of signatories were starting in Istanbul on charges of "making propaganda for a terrorist organization". ${ }^{77}$ Many others have lost their jobs and sometimes had passports and other documents confiscated leaving them unable to find other work. Turkish academics working abroad, who signed the petition, feel unable to visit Turkey for fear of arrest and the cumulative effect is one of significant deterrent effect on academic freedom within Turkish universities.

The AKP's discourse on Syrian Kurdish issues has also continued to be based within a terrorist narrative. Erdoğan was critical of the USA's cooperation with the PYD and the YPG in the fight against Islamic State. He was particularly disparaging of Washington's reluctance to name them as proscribed terror organisations.

"Hey America! How many times have we had to tell you? Are you together with us or are you with the PYD and YPG terror groups? As you have never recognized them (as terror groups) the region has turned into a pool of blood." 78

Erdoğan was insistent the Syrian Kurdish groups were "terrorists":

\footnotetext{
75 'Trapped in war zone, locals struggle in Turkey curfew towns', Agence France Presse, December 23, 2015.

76 'Turkey probes academics over rebel crackdown petition', Agence France Presse, January 14, 2016.

77 Judith Butler and Basak Etur, 'Trial begins in Turkey for Academics for Peace', Critical Legal Thinking: Law and the Political. December 11, 2017. http://criticallegalthinking.com/2017/12/11/trials-begin-turkeyacademics-peace/

78 'Turkey's Erdoğan lambasts US over support for Syrian Kurds', Agence France Presse, February 11, 2016.
} 
"Is there a difference between the PKK and the PYD? Is there a difference with the YPG?" asked Erdoğan. We have written proof! We tell the Americans 'it's a terror group'. But the Americans stand up and say 'no we don't see them as terror groups'." 79

This use of language is a blatant and clear linking of the PYD and the PKK and in February 2016 the Turkish government admitted carrying out airstrikes on PYD/YPG targets inside Syria ${ }^{80}$ which was justified by the terrorist label. Moreover this statement by one of his key advisors, Ibrahim Kalin, said the Syrian Kurdish forces were establishing a Kurdish autonomous region in northern Syria "under the cover of fighting Daesh (IS)." The pro AKP Yeni Safak newspaper said in an editorial:

"If it (the United States) is choosing a terror organisation over Turkey, no problem, so be it...but we are going to say: 'The US is waging a war on Turkey'." 81

Hence, the Academics for Peace can be seen as a critical voice delegitimized by this discursive strategy. The AKP campaign against the HDP has also deteriorated further since the November 2015 general election. In January 2016 the Turkish government launched a criminal investigation into the party's co-leaders, Demirtaş and Yüksekdağ and called for their immunity as sitting members of parliament to be lifted because of terrorist activities. Erdoğan said the co-leaders should "pay the price" as "...we cannot accept statements calling for the country to be broken up. We will never agree to a state within a state."

"I believe that the lifting of immunity of those against whom the cases have been initiated will help the atmosphere in our country in the fight against terror in a positive way." 82

The AKP's deputy chairman Selçuk Özdağ said anyone who "damaged the integrity of the country, supported terror or who hurts unity" should have no immunity.

\footnotetext{
79 'Turkey's Erdoğan lambasts US over support for Syrian Kurds', Agence France Presse, February 11, 2016.

80 'Risking rift with US, Turkey confronts Syrian Kurds', Agence France Presse, February 14, 2016.

81 'Risking rift with US, Turkey confronts Syrian Kurds', Agence France Presse, February 14, 2016.

82 'Erdoğan backs criminal probe against Kurdish party chiefs', Agence France Presse, January 2, 2016.
} 
"It does not matter which party someone is from: immunity should not be used as a shield against criminal proceedings over grave crimes...no-one should have the freedom to commit crimes... the HDP has already overstepped the mark," 83

In November 2016 Demirtaş and Yüksekdağ were arrested and remanded in prison pending trial along with nine other HDP MPs. Both remain in prison on charges of "managing a terror organisation" and "making propaganda for a terror group". At the time of writing, Demirtaş has gone on trial and faces a jail term of 15 years. ${ }^{84}$

In addition to politicians and academics, human rights activists have also been arrested on "terror" charges. Nine members of Amnesty International staff in Istanbul, including a German and Swedish national, were detained in July 2017 on vague "terror" charges which alluded to links with the Gülen movement and the attempted coup of July $2016 .{ }^{85}$ When the charges were published in October 2017 the group were charged with "aiding" and/or being a member of various organisations outlawed by Turkey as "terror" groups including the Kurdistan Workers Party (PKK), the Gülenist movement and a far-left group, the Revolutionary People's Liberation Party-Front (DHKP-C). All but one of the group were released in November 2017 with the remaining detainee being Taner Kılıç the Amnesty International Chairperson for Turkey who remains charged with membership of the Gülen movement and involved in the failed coup d'état of July $2016 .{ }^{86}$

\section{Silencing opposition}

This paper is not making a case, one way or the other, about PKK status as a terrorist organisation. There is no doubt it has carried out acts of political violence since the $1980 \mathrm{~s}$ and the same applies to the PKK offshoot, the Kurdistan Freedom Hawks (TAK - Teyrebazen Azadiya Kurdistan). Neither is it arguing that Kurdish associated political groups are the only ones to have been labelled in this way. The far-left group, the Revolutionary People's Liberation Party-Front (DHKP-C - Devrimci Halk Kurtuluş Partisi-Cephesi) is also included and the Fetullah Gülen movement has been referred to as FETÖ (Fetullahci Terrorist

\footnotetext{
83 'Turkish parliament to consider lifting Kurdish leaders' immunity: report', Agence France Presse, January 3, 2016.

84 'Trial begins of pro-Kurdish leader in Turkey on 'terror' links', Agence France Presse, December 7, 2017.

85 'Amnesty says Turkey director, activists detained in Istanbul' Agence France Presse, July 6, 2017.

86 'Turkey court keeps regional Amnesty chief behind bars', Agence France Presse, November 22, 2017.
} 
Organisation) since February 2015. However, these are outside the scope of this article which is considering how the terrorism label has been used instrumentally by the AKP on Kurdish issues. Islamic State is also considered because of links with the Kurdish issue in Syria.

For whilst political violence is a reality, "terrorism" is a social construct "...decided by social agreement and inter-subjective practices." 87 Following the securitisation theory of Buzan et al 1998 and the Copenhagen School it is argued that Kurdish voices who posed either direct political opposition (HDP) or perceived external threats to the integrity of the Turkish state (PYD) were securitized by rhetorically linking them to the "terrorism" of the PKK. This treatment was later extended to pro-Kurdish - or pro-human rights - voices in academia and civil society. Given the domination of Turkish news media by the AKP and the state (Freedom House 2014), there was very little scrutiny or critique of this securitising rhetoric and hence it had instrumental value to the AKP. However, the referent object of this securitisation process is not the same in all cases. For the PYD, and later for IS, the referent object was the Turkish state and the general population whereas for the HDP and for civil society groups, the referent object is the AKP itself.

\begin{tabular}{|c|c|c|c|c|}
\hline Actors & $\begin{array}{l}\text { Political } \\
\text { opposition? }\end{array}$ & $\begin{array}{l}\text { Scrutinising } \\
\text { voice? }\end{array}$ & $\begin{array}{l}\text { State as referent } \\
\text { object? }\end{array}$ & $\begin{array}{l}\text { AKP as referent } \\
\text { object? }\end{array}$ \\
\hline HDP & $x$ & & & $x$ \\
\hline PYD & $x$ & & $x$ & \\
\hline Islamic State & $x$ & & $x$ & \\
\hline $\begin{array}{l}\text { Academics for } \\
\text { peace }\end{array}$ & & $x$ & & $x$ \\
\hline $\begin{array}{l}\text { Amnesty } \\
\text { International }\end{array}$ & & $\mathrm{x}$ & & $x$ \\
\hline
\end{tabular}

In the case of the Syrian Kurdish PYD the referent object is the Turkish state. By association with the PKK the PYD is seen to be part of a movement which could strengthen the influence of the PKK and its desire for more autonomy within Turkey. Prima facie however, the PYD and its militia the YPG, were primarily involved in the Syrian Civil War - against both the Assad government and the Islamic State. Although it cannot be denied that, given victory in

\footnotetext{
87 Jackson, Writing the War on Terrorism, 248.
} 
Syria, the PYD might not support the PKK in Turkey this was not its primary aim at the time in question. With the Islamic State, whilst the Turkish government initially appeared reluctant to label Islamic State as a terrorist organisation it has since become seen as a threat to the security of the Turkish state and its people. Moreover, it is a means by which Erdoğan has sought to position Turkey as a fellow victim of IS terrorism after the Paris and Brussels attacks - and a means through which to call on the EU to restrict the activities of Kurdish lobby groups in Brussels.

The referent object of the HDP, on the other hand was the AKP. When it won more than $10 \%$ of the vote in the June 2015 general election, the HDP became a threat to the ambition of Erdoğan and the AKP to establish an executive presidency ${ }^{88}$. Its larger vote share had removed the AKP's parliamentary majority making the transition to executive rule more problematic. There followed a repeated discursive association of the HDP with the PKK in the summer of 2015 - which coincided with the resumption of hostilities with the PKK and the second general election campaign. The rhetorical association of the HDP with terrorism, and conversely the AKP with stability and security in the second general election campaign, is seen as a contributory factor to the AKP securing a larger majority in November 2016 and hence being able to hold a referendum which established Erdoğan in the presidential palace.

Lastly, since 2016 the terror label has been applied to areas of academia and civil society due to scrutinising or critical comments about human rights abuses on Kurdish issues. These groups are not active supporters of the PKK - and have no broad historical or familial affiliation which could be construed as such, as is the case with the HDP (and Demirtaş' brother Nurettin for example). Instead they are said to be terrorist supporters merely for highlighting human rights abuses against civilians. By not actively supporting the AKP position they are opposing it - and by opposing it they are deemed to be supporting the Kurdish cause narrowly defined as "terrorism". In the case of the academics for peace petition this has served to quash freedom of speech on campuses across Turkey. Similarly the grounds for accusation of the Istanbul Amnesty employees was the expression of concern by Amnesty of human rights irregularities including the cases of Demirtaş and

\footnotetext{
${ }^{88}$ Berk Esen \& Şebnem Gümüşçü, 'A Small Yes for Presidentialism: The Turkish Constitutional Referendum of April 2017', South European Society and Politics, 22, no. 3, (2017): 303-326.
} 
Yüksekdağ. In both cases this sends a wider deterrent message across academia and civil society and acts as a future deterrent to further scrutiny of AKP policy. It can therefore be seen as a deterrent to criticism of the AKP, the referent object in this particular case of securitisation.

Hence the AKP, as the ruling government with a parliamentary majority has had the power to label groups posing an external threat to the Turkish state or political opposition as terrorist and this has served as an effective way of limiting their influence and delegitimising the cause. At the same time it de-securitized Islamic State by downplaying its "terrorist" status and conflating it with other terrorist groups, until it became impossible not to do so. After that point it adopted a victim persona in solidarity with France and Belgium and tried to use this sympathy to further limit the activities of Kurdish lobby groups in Brussels.

The consequence has been that Turkey has become an illiberal state in which measures such as the rule of law and the right to free expression are clearly compromized by this abuse of power on terror legislation. It is used instrumentally by the state to bolster its own position - and specifically that of President Erdoğan. The inevitable deterrent effect of this strategy has further reduced the number of critical and/or scrutinising voices usually provided by political opposition and civil society including academia and already curtailed by the AKP domination of the news media. This is both a symptom of the authoritarianism of Erdoğan and a contributory factor to the sustainability of it.

\section{Conclusion}

The contention of this paper is that the AKP government has a discursive strategy which has used the "terror" label instrumentally: firstly to discredit domestic political and strategic opponents by associating them with the PKK and, secondly, to elicit sympathy for itself at home and abroad as a victim of Islamic State terrorism. In the case of the PYD this put them on the negative side of the good Kurd/bad Kurd divide with the Iraqi Peshmerga and stoked discontent in Turkish Kurdish areas as well because of IS activity in Kobane. Moreover, it justified Turkish military activity in northern Syria designed to prevent the Syrian Kurdish forces from establishing a power base. The electoral chances of the HDP in the second 2016 general election were hampered both by the resumption of hostilities between the Turkish state and the PKK and by Islamic State activity as well which the HDP was also discursively 
associated with. Furthermore, academics and human rights activists who expressed concern for civilian casualties of the eastern conflict have also been labelled as terrorist sympathisers. The creation of a binary distinction between the "state" and the "terrorists" or terror sympathizers enabled their de-legitimisation in the AKP's favour.

This can be contrasted with a reluctance to apply the same terrorist discourse to Islamic State until late 2015 in the face of considerable evidence to the contrary. Hence, the discursive strategy is to construct and deconstruct an association with "terror" activity instrumentally ie: there is securitisation and de-securitisation of "terror" to suit the interests of the AKP. Ironically in the case of Islamic State there was de-securitisation and then resecuritisation once the gravity of their violence, and the opportunity to present Turkey as one of several international victims of IS terror was clear. Theoretically, this would not be possible without the metatheoretical post-positivist presumption of a social reality created through discourse and the ability of language to contain power relationships.

In terms of securitisation theory both the Turkish state and the AKP can be seen as discursively placed referent objects. In this respect the strategy against the PYD can be seen as countering a threat to the Turkish state. However, it could also be viewed as countering the build-up of a pan-Kurdish power base with Turkish and Syrian Kurds which could form an electoral threat to the AKP. The discursive strategy as a whole can ultimately be understood if it is seen through the lense of AKP self-interest and the establishment of an authoritarian power base.

This pattern of behaviour continues to the time of writing as Demirtaş and Yüksekdağ remain imprisoned on terror charges as does a leading official of Amnesty International in Turkey. However, the strategy does show signs of becoming more erratic and hubristic: academia and civil society are not such obvious discursive targets for the AKP's terror rhetoric and to do so has tested the credulity of Turkey's international interlocutors. Moreover, the charges against them on Kurdish issues are increasingly being expediently conflated with the Gülen movement which further damages the liberal democratic credibility of the AKP government in international diplomatic circles, including the EU. 